\title{
Właściwości spoin stali obrabianych termomechanicznie o wysokiej granicy plastyczności
}

\section{Properties of thermomechanically treated welds of high yield point steel}

\section{Streszczenie}

W artykule przedstawiono właściwości spoin stali obrabianej termomechanicznie $\$ 700$ MC o grubości $10 \mathrm{~mm}$ wykonanych różnymi metodami spawania, przy różnych energiach liniowych. Badania metalograficzne, wytrzymałościowe oraz pomiar twardości pozwoliły na ocenę struktury i właściwości spoin oraz określenie wpływu ilości ciepła dostarczonego do obszaru spawania na wytrzymałość na rozciąganie, udarność i twardość spoin.

\section{Abstract}

The article presents the properties of thermomechanically treated welds of S700 MC $10 \mathrm{~mm}$ thick steel. Welds are made with various methods of welding, and with different welding energies. The metallographic study, tensile test results and hardness measurement show the structure and properties of the welds. Moreover, it is obtained the effect of heat input to the welding area on the tensile strength, toughness and hardness of welds.

\section{Wstęp}

W ostatnich latach obserwuje się wzrost światowego udziału konstrukcji spawanych wykonanych ze stali o podwyższonej i wysokiej granicy plastyczności. Wymagania jakościowe stawiane $w$ takich gałęziach przemysłu, jak: stoczniowy, budowy dróg i mostów, hydroenergetyki i energetyki jądrowej, konstrukcji platform wiertniczych, rurociągów oraz maszyn budowlanych sprawiły, że opracowano i wdrożono nowe technologie w dziedzinie metalurgii stali oraz obróbki plastycznej i cieplnej pozwalające na uzyskanie finalnych wyrobów w postaci blach i rur o wysokiej wytrzymałości bez obniżenia ich właściwości plastycznych. Opracowanie nowych gatunków stali spawalnych oraz wzrost wymagań stawianych konstrukcjom spawanym zmusza do podjęcia szczegółowych badań nad czynnikami wpływającymi na zachowanie się tych materiałów w czasie spawania i wykonanych z nich konstrukcji podczas eksploatacji. Przykładem mogą być spawalne stale

Dr inż. Jacek Górka - Politechnika Śląska, Gliwice

walcowane termomechanicznie, zwłaszcza te, które osiągają granicę plastyczności rzędu $700 \mathrm{MPa}$. Wprowadzenie stali obrabianych termomechanicznie o wysokiej granicy plastyczności i stosunkowo niskim równoważniku węgla pozwoli w znacznym stopniu ograniczyć czas wykonywania prac spawalniczych przez obniżenie temperatury podgrzania wstępnego lub nawet całkowitą rezygnację z tego zabiegu, zmniejszenie przekrojów elementów konstrukcyjnych, dzięki czemu konstrukcje spawane o tej samej nośności będą bardziej smukłe i lżejsze. Zastosowanie takich stali obniży koszty spawania w wyniku zmniejszenia przekroju spoin, co prowadzi do zmniejszenia zużycia materiałów dodatkowych, skrócenia czasu spawania, mniejszych nakładów na prostowanie konstrukcji i badanie spoin $[1,2]$. Aspekty techniczne i ekonomiczne wynikające z możliwości wytwarzania wyrobów hutniczych z tych stali w energooszczędnych zintegrowanych liniach produkcyjnych oraz ich przydatność do budowy różnorodnych konstrukcji, w tym także eksploatowanych w ekstremalnie trudnych warunkach klimatycznych, decydują o zainteresowaniu naukowym tą grupą materiałów i doskonaleniu technologii ich wytwarzania i łączenia metodami spawalniczymi (rys. 1). 

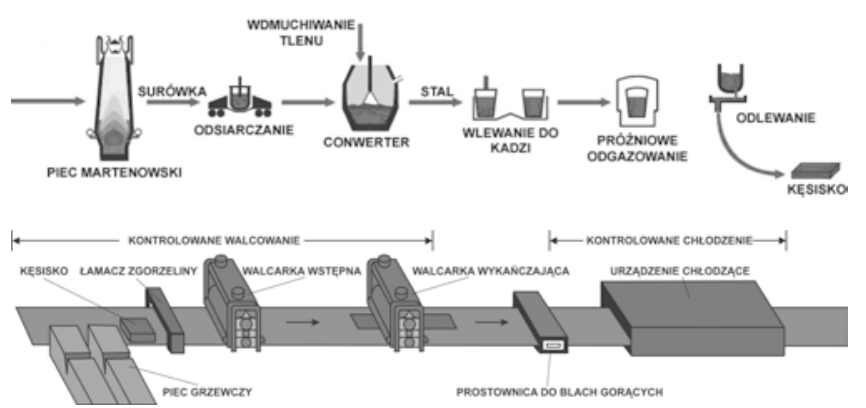

Rys. 1. Schemat linii produkcyjnej do wytwarzania stali $\operatorname{TMCP}[3,4]$

Fig. 1. Scheme of the production line of TMCP steel $[3,4]$

Przydatność tych materiałów do wytwarzania konstrukcji spawanych bardzo często zależy od czynników, które do tej pory były uwzględniane w niewielkim stopniu przy ocenie ich spawalności. Istotnym problemem w tych stalach jest wpływ mikrododatków stopowych (niobu, wanadu) na spawalność i właściwości połączeń spawanych. Rola mikrododatków w tych stalach sprowadza się do wytworzenia, w czasie kontrolowanego walcowania, odpowiedniej dyspersji wydzieleń węglików, azotków i węglikoazotków niobu i wanadu podwyższających ich właściwości wytrzymałościowe przez umocnienie wydzieleniowe i ograniczenie wiel-

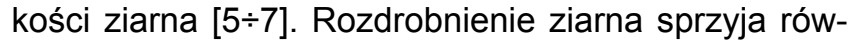
nież zachowaniu dobrych właściwości plastycznych stali. Badania spawalności ujawniły, że duże trudności przy spawaniu stali obrabianych termomechanicznie sprawiają właściwości spoin, a w mniejszym stopniu właściwości SWC. Czynnikiem mogącym mieć wpływ na właściwości spoin stali obrabianych termomechanicznie są niekontrolowane procesy wydzieleniowe faz międzymetalicznych MX (drobnodyspersyjne wydzielenia węglików/węglikoazotków $\mathrm{Nb}(\mathrm{C}, \mathrm{N}), \mathrm{V}(\mathrm{C}, \mathrm{N})$ i innych), które w znacznym stopniu mogą obniżać właściwości plastyczne spoin i odporność na pękanie [5:7]. Wydzielanie się faz MX jest procesem dyfuzyjnym, którego szybkość można określić za pomocą dyfuzji wyrażonej wzorem Arrheniusa [8]:

$$
\mathrm{D}=\mathrm{D}_{\mathrm{o}} \exp (-\mathrm{Q} / \mathrm{RT})
$$

gdzie: $D_{o}$ - stała, $\mathrm{m}^{2} / \mathrm{s}, \mathrm{Q}$ - energia aktywacji dyfuzji, $\mathrm{R}$ - stała gazowa, $T$ - temperatura bezwzględna.

Tablica I. Skład chemiczny wg PN EN 10149-2 i właściwości mechaniczne stali S700 MC walcowanej termomechanicznie do kształtowania na zimno Table I. Chemical composition acc. to PN EN 10149-2 and mechanical properties of thermomechanical rolled S700 MC steel for cold forming

\begin{tabular}{|c|c|c|c|c|c|c|c|c|c|c|c|}
\hline \multicolumn{12}{|c|}{ Stężenie pierwiastków, \% wag. } \\
\hline $\mathrm{C}$ max. & Si max. & Mn max. & $\mathrm{P}$ max. & S max. & $\mathrm{Al}_{\text {catk }} \min$. & Nb max*. & $V$ max. & Ti max. & B max. & Mo max. & $\mathrm{Ce}^{* *} \max$ \\
\hline 0,12 & 0,60 & 2,10 & 0,008 & 0,015 & 0,015 & 0,09 & 0,20 & 0,22 & 0,005 & 0,50 & 0,61 \\
\hline \multicolumn{12}{|c|}{ Właściwości mechaniczne } \\
\hline \multicolumn{3}{|c|}{ Wytrzymałość na rozciąganie $R_{m}, M P a$} & \multicolumn{3}{|c|}{ Granica plastyczności $R_{\mathrm{e}}, \mathrm{MPa}$} & \multicolumn{3}{|c|}{ Wydłużenie $A_{5}, \%$} & \multicolumn{3}{|c|}{ Udarność, $\mathrm{J} / \mathrm{cm}^{2} \quad\left(-20^{\circ} \mathrm{C}\right)$} \\
\hline \multicolumn{3}{|c|}{822} & \multicolumn{3}{|c|}{768} & \multicolumn{3}{|c|}{19} & \multicolumn{3}{|c|}{135} \\
\hline \multicolumn{12}{|c|}{ * Suma zawartości $\mathrm{Nb}, \mathrm{V}$ i Ti powinna wynosić max. 0,22\%, ** $\mathrm{Ce}$ - równoważnik węgla liczony wg wzoru $\quad \mathrm{Ce}=\mathrm{C}+\frac{\mathrm{Mn}}{6}+\frac{\mathrm{Cr}+\mathrm{Mo}+\mathrm{V}}{5}+\frac{\mathrm{Ni}+\mathrm{Cu}}{15} \%$} \\
\hline
\end{tabular}

Tablica II. Skład chemiczny stali S700 MC

Table. II. Chemical composition of S700 MC steel

\begin{tabular}{|c|c|c|c|c|c|c|c|c|c|c|}
\hline \multicolumn{10}{|c|}{ Stężenie pierwiastków, \% wag. } \\
\hline $\mathrm{C}$ & $\mathrm{Mn}$ & $\mathrm{Si}$ & $\mathrm{S}$ & $\mathrm{P}$ & $\mathrm{Al}$ & $\mathrm{Nb}$ & $\mathrm{Ti}$ & $\mathrm{V}$ & $\mathrm{N}^{*}$ & $\mathrm{Ce}$ \\
\hline 0,056 & 1,68 & 0,16 & 0,005 & 0,01 & 0,027 & 0,044 & 0,12 & 0,006 & 72 & 0,33 \\
\hline
\end{tabular}

Warto również zwrócić uwagę na niekorzystny wpływ azotu, który odpowiada za procesy starzenia. Sam materiał rodzimy zawiera wystarczającą ilość aktywnego w stosunku do azotu tytanu i aluminium, które tworzą TiN i AIN. W spoinie zawartość tytanu będzie zależała od parametrów spawania i przy zbyt dużej zawartości azotu w stali może być niewystarczająca do ograniczenie właściwości eksploatacyjnych spoin.

\section{Badania własne}

Stale konstrukcyjne walcowane termomechanicznie są uznawane za dobrze spawalne ze względu na wysoką czystość metalurgiczną oraz niski równoważnik węgla $C_{e}[5,6]$. Spotykane $w$ literaturze zalecenia odnośnie spawania stali obrabianych termomechanicznie dotyczą materiału dodatkowego do spawania, ograniczenia wodoru w spoinie dzięki stosowaniu procesów niskowodorowych oraz ograniczenia temperatury podgrzania wstępnego, która powinna być $50 \div 80^{\circ} \mathrm{C}$ niższa niż w przypadku stali normalizowanych oraz ulepszanych cieplnie i nie powinna przekraczać $100^{\circ} \mathrm{C}$. Uzyskanie spoin o właściwościach zbliżonych do właściwości tych stali $\left(R_{m}, K V\right)$ wymaga zastosowania spoiw o wyższej niż $w$ materiale rodzimym zawartości składników stopowych, co wiąże się z podwyższeniem równoważnika węgla oraz możliwością pogorszenia spawalności wskutek niekontrolowanych procesów wydzieleniowych w obszarze spoiny. W konsekwencji w przypadku złączy spawanych stali obrabianych termomechanicznie uzyskuje się spoiny niejednorodne pod względem struktury i składu chemicznego (równoważnik węgla). Skład chemiczny spoiny i wartość równoważnika węgla jest więc wypadkową stopnia wymieszania materiału spawanego i zastosowanego spoiwa [9]. W pracy poddano badaniom złącza ze stali S700 MC (tabl. I i II, rys. 2) o grubości $10 \mathrm{~mm}$ spawane różnymi metodami w pozycji podolnej (tabl. III), temperatura podgrzewania osuszającego wynosiła $80^{\circ} \mathrm{C}$, temperatura międzywarstwowa $65^{\circ} \mathrm{C}$. trwałe i mało rozpuszczalne $w$ austenicie wydzielenia nia procesów starzeniowych, co spowoduje pogorsze- 


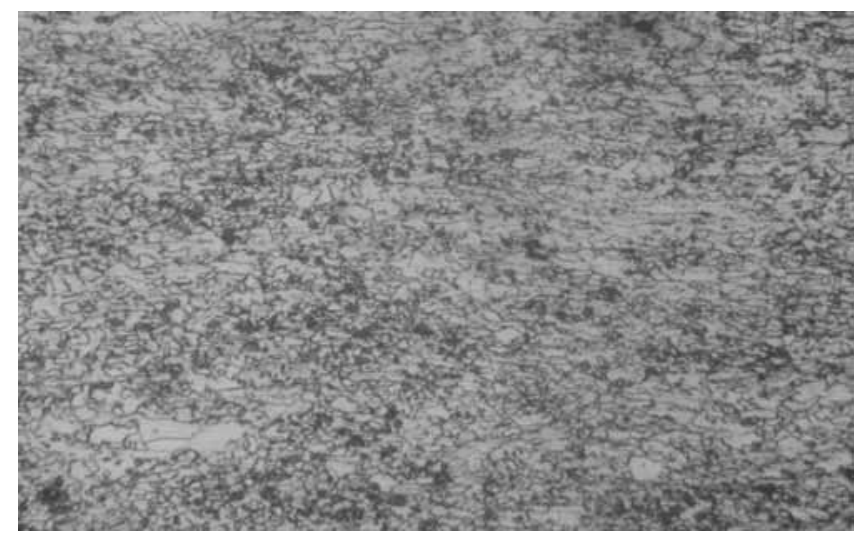

Rys. 2. Bainityczno-ferrytyczna mikrostruktura stali obrabianej termomechanicznie S700MC

Fig. 2. Bainite-ferritic microstructure of thermomechanically treated S700MC steel

Tablica III. Wykonane złącza próbne do badań

Table III. Sample joints for testing

\begin{tabular}{|c|c|c|c|}
\hline Oznaczenie & $\begin{array}{c}\text { Metoda } \\
\text { spawania }\end{array}$ & Spoiwo & $\begin{array}{c}\text { Wprowadzona } \\
\text { energia liniowa, } \mathrm{KJ} / \mathrm{cm}\end{array}$ \\
\hline MAG + w & $\begin{array}{c}\text { MAG drutem } \\
\text { litym } \\
\text { z wygrzewaniem } \\
\text { po spawaniu }\end{array}$ & $\begin{array}{c}\text { G Mn4Ni1,5Cr- } \\
\text { Mo }\end{array}$ & $\begin{array}{c}8 \\
\text { Po spawaniu } \\
\text { podgrzewanie } \\
\text { do temperatury } 170 \div 180^{\circ} \mathrm{C} \\
\text { i bardzo wolne studzenie } \\
\text { przez zawinięcie } \\
\text { w koce izolacyjne }\end{array}$ \\
\hline MAG DL & MAG drutem litym & G Mn3Ni1CrMo & 7,5 \\
\hline MAG DP & $\begin{array}{c}\text { MAG drutem } \\
\text { proszkowym }\end{array}$ & T Mn2NiMo & 6 \\
\hline SAW & Łuk kryty & S Mn3NiMo1 & 35 \\
\hline MMA & MMA & E Mn2NiCrMo & 9 \\
\hline TIG & TIG & G Mn2NiMoCr & 28 \\
\hline
\end{tabular}

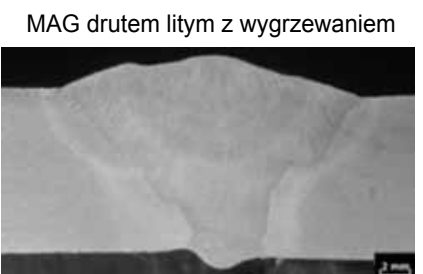

MAG drutem proszkowym

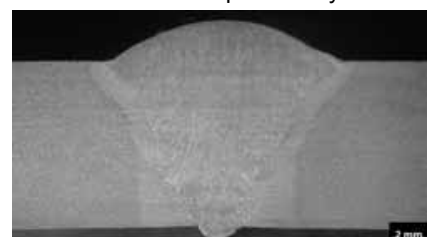

MMA

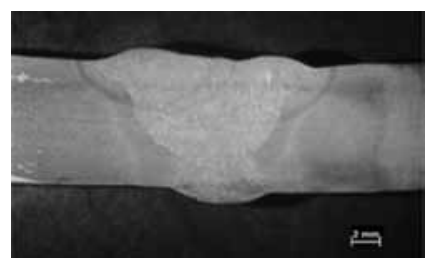

Rys. 3. Makrostruktura załączy spawanych ze stali S700 MC, trawienie: Adler

Fig. 3. Macrostructure of welded joints of S700 MC steel, etching: Adler

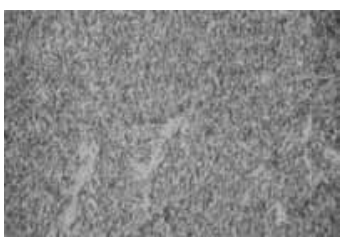

MAG drutem proszkowym

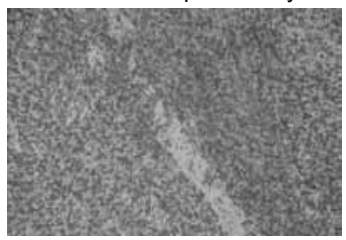

MMA

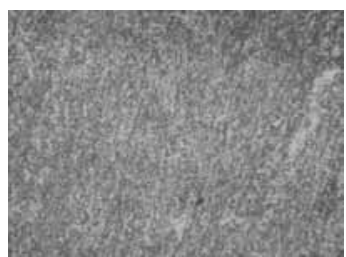

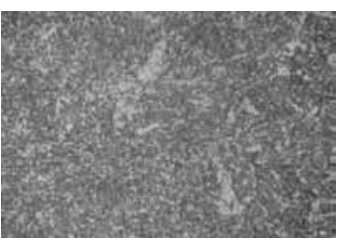

Łuk kryty

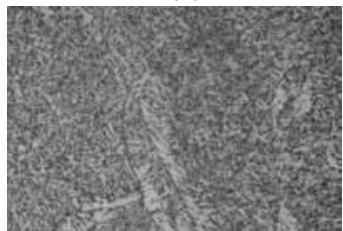

TIG

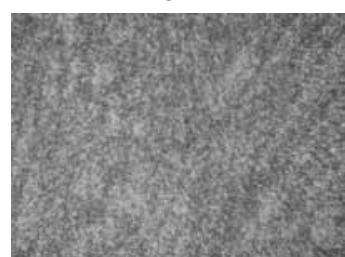

Rys. 4. Mikrostruktura spoiny złączy spawanych ze stali S700MC, trawienie: nital, pow. 200x

Fig. 4. Microstructure of welded joints of S700MCsteel, etching: nital, magn. $200 x$

\section{Badania metalograficzne}

Wykonane złącza spawane poddano badaniom metalograficznym makroskopowym (rys. 3), na mikroskopie stereoskopowym Olympus SZX9 oraz badaniom mikroskopowym na mikroskopie świetlnym LEICA MEF4A w obszarze spoiny (rys. 4).

\section{Badania wytrzymałościowe}

Wykonane złącza spawane poddano badaniom wytrzymałości na rozciąganie, próbie zginania od strony lica i od strony grani oraz badaniom udarności w obszarze spoiny w temperaturze $-30^{\circ} \mathrm{C}$. Wyniki prób wytrzymałościowych przedstawiono w tablicy IV.

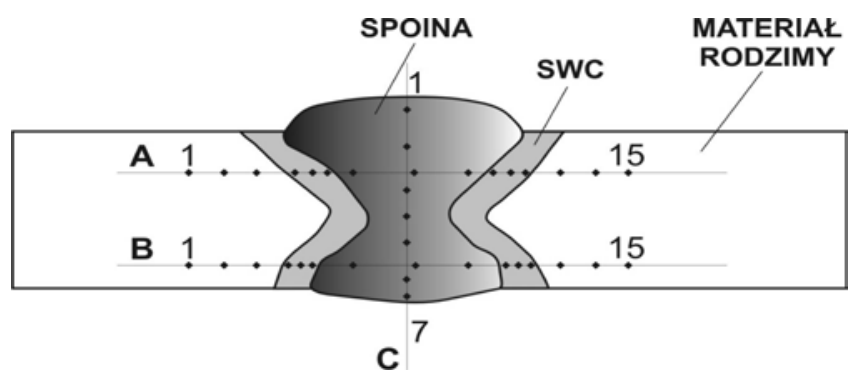

Rys. 5. Schemat rozmieszczenia punktów pomiaru twardości złącza spawanego ze stali S700 MC

Fig. 5. Hardness measurement points distribution scheme of the S700 MC steel welded joint 
Tablica IV. Wyniki badań wytrzymałościowych złączy spawanych ze stali S700 MC

Table IV. Results of strength tests of welded joints of S700 MC steel

\begin{tabular}{|c|c|c|c|c|c|c|}
\hline \multirow{2}{*}{ Metoda spawania } & \multicolumn{2}{|c|}{ Rozciąganie } & \multicolumn{2}{|c|}{ 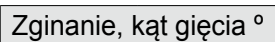 } & \multicolumn{2}{|c|}{ Udarność, $-30^{\circ} \mathrm{C}$} \\
\hline & $\mathrm{R}_{\mathrm{m}}, \mathrm{MPa}$ & miejsce zerwania & lico & grań & $\mathrm{KV}, \mathrm{J} / \mathrm{cm}^{2}$ & przełom \\
\hline MAG drutem litym z wygrzewaniem po spawaniu & 790 & spoina & 180 & 180 & 25 & kruchy/bez wad \\
\hline MAG drutem litym & 860 & MR & 180 & 180 & 78 & mieszany/bez wad \\
\hline MAG drutem proszkowym & 840 & MR & 180 & 180 & 70 & mieszany/bez wad \\
\hline Łuk kryty & 730 & spoina & 180 & 180 & 75 & mieszany/bez wad \\
\hline MMA & 820 & przejście & 180 & 180 & 88 & mieszany/bez wad \\
\hline TIG & 750 & spoina & 180 & 180 & 30 & kruchy/bez wad \\
\hline
\end{tabular}

Tablica V. Wyniki rozkładu twardości HV30 w obszarach złącza spawanego stali S700 MC

Table V. Results of HV30 hardness distribution in the areas of the welded joint of S700 MC steel

\begin{tabular}{|c|c|c|c|c|c|c|c|c|c|c|c|c|c|c|c|}
\hline \multirow{2}{*}{ Linia pomiarowa } & \multicolumn{15}{|c|}{ Punkty pomiarowe, wg rys. 5} \\
\hline & 1 & 2 & 3 & 4 & 5 & 6 & 7 & 8 & 9 & 10 & 11 & 12 & 13 & 14 & 15 \\
\hline & \multicolumn{15}{|c|}{ MAG drutem litym z wygrzewaniem po spawaniu } \\
\hline A & 278 & 282 & 286 & 240 & 242 & 232 & 272 & 283 & 295 & 258 & 247 & 246 & 289 & 288 & 279 \\
\hline $\mathrm{B}$ & 280 & 285 & 284 & 249 & 235 & 246 & 280 & 272 & 278 & 247 & 234 & 244 & 285 & 280 & 284 \\
\hline \multirow[t]{2}{*}{$\mathrm{C}^{*}$} & 278 & 275 & 282 & 269 & 272 & 268 & 265 & & & & & & & & \\
\hline & \multicolumn{15}{|c|}{ MAG drutem litym } \\
\hline$A$ & 282 & 279 & 282 & 271 & 262 & 273 & 294 & 299 & 280 & 257 & 274 & 265 & 285 & 282 & 278 \\
\hline $\mathrm{B}$ & 279 & 284 & 282 & 263 & 278 & 269 & 283 & 287 & 279 & 263 & 259 & 270 & 279 & 283 & 280 \\
\hline \multirow[t]{2}{*}{$\mathrm{C}^{*}$} & 284 & 286 & 284 & 270 & 268 & 269 & 258 & & & & & & & & \\
\hline & \multicolumn{15}{|c|}{ MAG drutem proszkowym osłonowym } \\
\hline A & 283 & 279 & 280 & 260 & 251 & 259 & 298 & 286 & 285 & 263 & 259 & 268 & 280 & 279 & 282 \\
\hline $\mathrm{B}$ & 280 & 281 & 284 & 259 & 263 & 265 & 288 & 284 & 292 & 265 & 259 & 262 & 281 & 278 & 280 \\
\hline \multirow[t]{2}{*}{$\mathrm{C}^{*}$} & 290 & 287 & 279 & 281 & 277 & 279 & 265 & & & & & & & & \\
\hline & \multicolumn{15}{|c|}{ Łukiem krytym } \\
\hline A & 285 & 279 & 281 & 246 & 251 & 243 & 226 & 236 & 238 & 245 & 241 & 251 & 279 & 280 & 282 \\
\hline$B$ & 280 & 280 & 279 & 239 & 245 & 248 & 236 & 228 & 231 & 240 & 248 & 250 & 282 & 281 & 281 \\
\hline \multirow[t]{2}{*}{$\mathrm{C}^{*}$} & 232 & 228 & 236 & 231 & 229 & 225 & 230 & & & & & & & & \\
\hline & \multicolumn{15}{|c|}{ MMA } \\
\hline A & 280 & 282 & 280 & 262 & 376 & 354 & 308 & 279 & 285 & 365 & 370 & 269 & 280 & 282 & 281 \\
\hline $\mathrm{B}$ & 280 & 281 & 282 & 242 & 241 & 234 & 254 & 262 & 259 & 231 & 234 & 250 & 282 & 281 & 281 \\
\hline \multirow[t]{2}{*}{$\mathrm{C}^{*}$} & 277 & 264 & 293 & 269 & 291 & 258 & 257 & & & & & & & & \\
\hline & \multicolumn{15}{|c|}{ TIG } \\
\hline A & 281 & 281 & 280 & 204 & 279 & 229 & 246 & 246 & 238 & 239 & 269 & 216 & 280 & 282 & 280 \\
\hline$B$ & 282 & 281 & 280 & 220 & 217 & 198 & 239 & 254 & 245 & 198 & 223 & 220 & 281 & 281 & 282 \\
\hline $\mathrm{C}^{*}$ & 246 & 245 & 257 & 280 & 273 & 262 & 266 & & & & & & & & \\
\hline
\end{tabular}

\section{Pomiary twardości}

W celu określenia wpływu procesu spawania na zmianę twardości w obszarze złączy spawanych przeprowadzono pomiar twardości metodą Vickersa przy obciążeniu 1 i 30 kG według schematu jak na rysunku 5. Wyniki pomiarów twardości przedstawiono w tablicy $\mathrm{V}$.

\section{Podsumowanie}

Ocenie poddano spoiny stali obrabianej termomechanicznie S700 MC wykonane różnymi metodami spawalniczymi oraz z różną ilością wprowadzonego ciepła do obszaru złącza spawanego. Badania metalograficzne makroskopowe nie wykazały występowania żadnych niezgodności spawalniczych. Wykazały natomiast, że spoina ma strukturę ferrytyczno-bainityczną.
Przeprowadzona we wcześniejszych pracach rentgenowska analiza fazowa w obszarze spoiny oprócz faz $\mathrm{Fe}_{\alpha}$ wykazała dodatkowo istnienie faz $\mathrm{Fe}_{\mathrm{y}}$, prawdopodobnie austenitu szczątkowego, który niekorzystnie wpływa na właściwości eksploatacyjne konstrukcji spawanych pracujących w warunkach obciążeń wytrzymałościowych i cieplnych [9]. Badania wytrzymałości na rozciąganie złączy spawanych wykazały, że przy zachowaniu energii liniowej spawania poniżej $10 \mathrm{~kJ} / \mathrm{cm}$ wytrzymałość złączy spawanych przewyższa wytrzymałość na rozciąganie materiału rodzimego. Zastosowanie wysokich energii liniowych spawania (powyżej $25 \mathrm{~kJ} / \mathrm{cm}$ ) prowadzi do wyraźnego obniżenia wytrzymałości na rozciąganie (rys. 6). Spowodowane jest to prawdopodobnie procesami częściowej rekrystalizacji i rozrostem ziarna w obszarach złącza spawanego.

Próba zginania wykazała, że złącza spawane charakteryzują się dobrymi właściwościami plastycznymi. W każdym przypadku osiągnięto kąt gięcia $180^{\circ}$ (tabl. IV), na powierzchni nie zaobserwowano żadnych

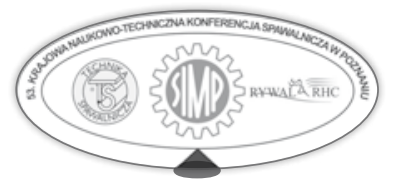




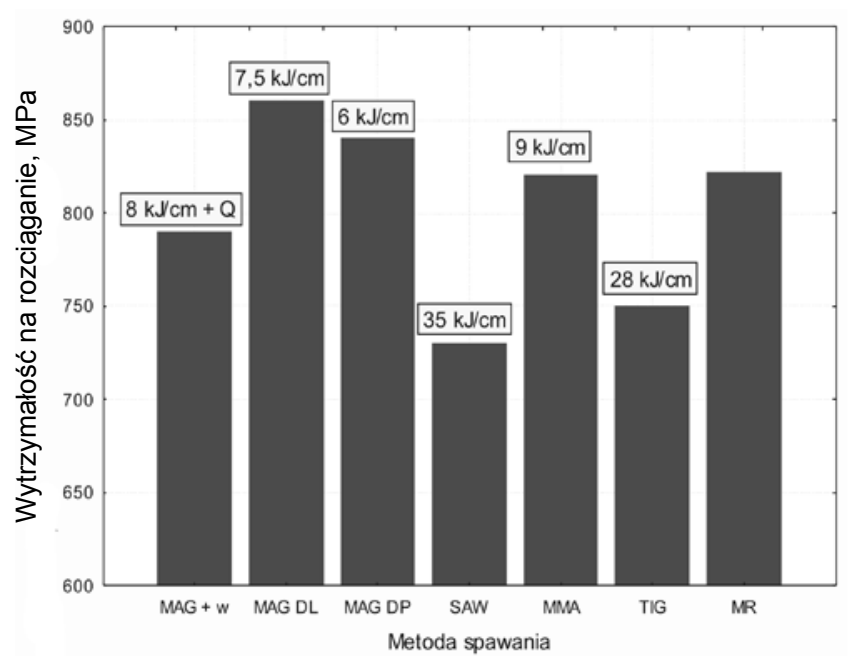

Rys. 6. Wytrzymałość na rozciąganie złączy spawanych ze stali S700 MC

Fig. 6. Tensile strength of the welded joints of S700 MC

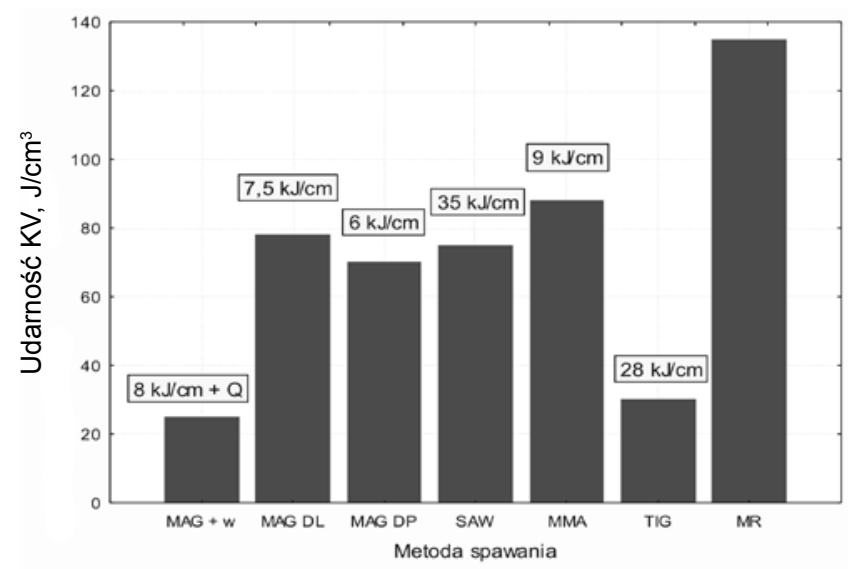

Rys. 7. Udarność spoin złączy spawanych ze stali S700 MC

Fig. 7. Impact strength of the welded joints of S700 MC

\section{Wnioski}

Należy stwierdzić, że w przypadku spawania stali obrabianych termomechanicznie o wysokiej granicy plastyczności bardzo ważna jest ilość ciepła wprowadzona do obszaru złącza spawanego. Energia liniowa spawania powinna być ograniczona do $10 \mathrm{~kJ} / \mathrm{cm}$. Również dodatkowe ciepło dostarczone do złącza po spawaniu może spowodować gwałtowne obniżenie właściwości złączy, zwłaszcza udarności materiału spoiny. Zbyt duża ilość ciepła dostarczona do obszaru złącza spawanego powoduje rekrystalizację oraz rozrost ziarna w obszarze SWC, co skutkuje utratą właściwości nabytych w wyniku obróbki termomechanicznej, a w spoinie może dochodzić do niekontrolowanych procesów wydzieleniowych pogarszających właściwości złączy spawanych.

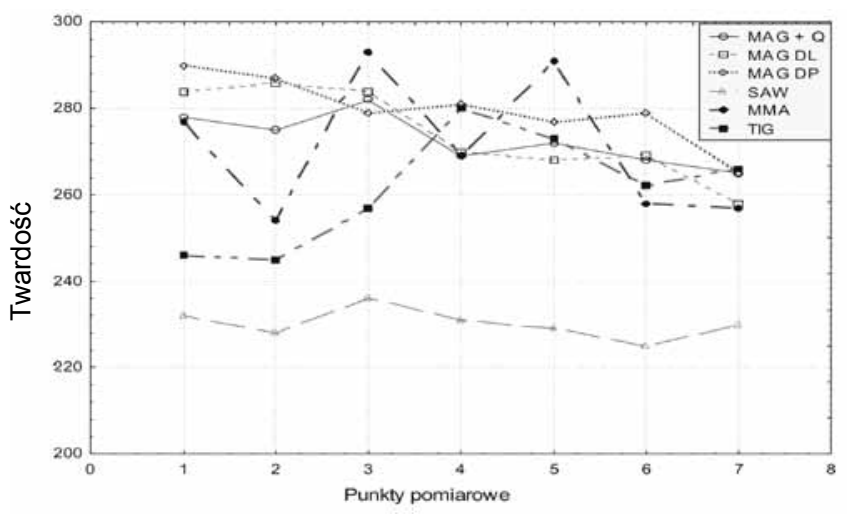

Rys. 8. Rozkład twardości w obszarze spoiny złączy spawanych ze stali S700 MC

Fig. 8. Hardness distribution in the welded joints of S700 MC

naderwań i rys. Badania udarności wykazały, że ilość ciepła wprowadzona do obszaru złącza silnie wpływa na właściwości spoiny. Przy niskich energiach liniowych spawania spoiny osiągają wysoką udarność rzędu $80 \mathrm{~kJ} / \mathrm{cm}^{2}$. Przy spawaniu metodą TIG energią liniową $28 \mathrm{~kJ} / \mathrm{cm}$ dochodzi do obniżenia udarności do poziomu dopuszczalnego $27 \mathrm{~J} / \mathrm{cm}^{2}$. Również przy spawaniu niską energią liniową metodą MAG z zastosowaniem wygrzewania po spawaniu dochodzi do gwałtownego obniżenia udarności poniżej $27 \mathrm{~J} / \mathrm{cm}^{2}$ (rys. 7). Utrata udarności spoin może być spowodowana drobnodyspersyjnymi wydzieleniami faz MX w ziarnach ferrytu i bainitu [10], ale wymaga to potwierdzenia dalszymi badaniami naukowymi. Pomiary twardości w obszarze spoiny wykazały, że twardość nie przekracza 300 HV1 (rys. 8). W przypadku złączy wykonanych łukiem krytym twardość jest wyraźnie niższa, ale związane jest to z właściwościami materiału spoiwa.

\section{Literatura}

[1] Tasak E.: Metalurgia spawania, Patria Kraków 2008.

[2] Brózda J.: Nowoczesne stale konstrukcyjne i ich spawalność, Wydawnictwo Instytutu Spawalnictwa, Gliwice 2009.

[3] Sueyoshi T., Ishikawa N., Iwase A.: The role of niobium in the retardation of the early stage of austenite recovery in hot-deformed steels. Materials Science and Engineering, vol. 250 (1998), No. 1, pp. 2-7.

[4] Ruukki, Materiały informacyjne firmy RUUKKI.

[5] Yurioka N.: TMPC steels and their welding. Welding in the World. Vol. 35, 6/1995.

[6] Tasak E.: Spawalność stali, Fotobit, Kraków 2002.

[7] Zając Z., Langeborg R., Siwecki T.: The role of nitrogen in microalloyed steels. Microalloying' 95. Pitsburg 1995.

[8] Gladman T.: The physical metallurgy of mikroalloyed steels, The Institute of Materials, Cambridge University Press, Cambridge 1997.

[9] Górka J.: Spawalność stali obrabianej termomechanicznie o wysokiej granicy plastyczności, Biuletyn Instytutu Spawalnictwa, nr 5/2010, s. 165-169.

[10] Gruszczyk A., Griner S.: Struktura i właściwości połączeń spawanych i zgrzewanych stali obrobionych termomechanicznie. Przegląd Spawalnictwa nr 5-6/2006. 